\title{
Various aspects of human functioning in the positive psychology perspective
}

The interest in positive psychology among scientists is steadily increasing all around the world. This can be seen at many scientific conferences on positive psychology such as the European conferences (held every two years), the annual World congresses or Polish conferences on this subject (the last was held in Poznan in May 2016).

This great interest is probably due to the definition of positive psychology, which is understood as a trend in research and psychological practice focused on these predispositions, abilities and skills, which can help people meet challenges, achieve a high quality of life, develop their own potential and better cope with difficulties in life. So, positive psychology as a specific perspective of looking at human functioning is applicable in many areas.

From the very beginning of its existence, it was emphasized that positive psychology is a science. The rigors of scientific method should be therefore applied to it. It should recognize and describe the given reality, in particular human behavior. It should explain the occurrence of phenomena and behaviors, as well as predict them based on psychological mechanisms. All these purposes should be realized objectively and based on facts, even if this explorations and descriptions, explanations and predictions are accompanied by a specific filter focused on what is positive. In hindsight, it can be seen that more and more often the temptation to move away from a purely scientific objectivity in favor of giving guidance on the "good life" appears among those involved in the promotion of positive psychology. A tendency to sacrificing of descriptions for prescriptions can be noticed (Tucholska and Gulla, 2007).

It seems that the desire of dissemination of positive psychology as broadly and as quickly as possible has caused mistrust of the broad scientific community, which began to treat it in terms of pop-psychology. This way of thinking appeared in the United States, the cradle of positive psychology, as well as in Poland. Interestingly, comments criticizing the trend in psychological scientific journals are not too many. Critical statements on the basic assumptions of positive psychology and methods of their implementation could be read already several years after the announcement of this trend (Gable and Haidt, 2005; Held, 2004; Sundararajan, 2005). Critical articles in which the authors tried to show both advantages and point out serious shortcomings and weaknesses of positive psychology have appeared in Poland as well (Gulla and Tucholska, 2007; Kwiatek and Wilczewska, 2015; Tucholska and Gulla, 2007). These critical publications probably have not radically changed the image of positive psychology.

Due to such ambiguous treatment of positive psychology, for example in the Polish scientific community, examples of reliable scientific articles written explicitly in the context of positive psychology is an extremely valuable phenomenon. This special issue is such an important step in promoting positive psychology as a reliable science.

This special issue gathers scientists from various research centers and dealing with the different areas, in which the perspective of positive psychology can be applied. Articles represent research analysis of both quantitative and qualitative methods.

This issue begins with three articles of a more general nature. Then there are several texts in the field of work psychology. At the end, there are two articles concerning questionnaires diagnosing variables important in the field of positive psychology.

The first article Cognitive and emotional predictors of episodic and dispositional forgiveness by Justyna Mróz and Kinga Kaleta, concerns one of the character strengths included in the Seligman's and Peterson's catalog. In their study, the authors checked the role played by cognitive (positive orientation, basic hope) and emotional (positive and negative affectivity, emotional control) variables for state and trait forgiveness.

In the next article, Knowledge about the joy in children with mild intellectual disability Aleksandra

\footnotetext{
University of Social Sciences and Humanities Faculty in Poznań, Department of Work and Organizational Psychology 
Jasielska and Marzena Buchnat have used their own tool to measure children's knowledge of emotions including joy. The cognitive representation of the basic emotions available in three codes: image, verbal, semantic and interconnection between the codes: perception, symbolization and conceptualization were used.

The community feeling versus anxiety, self-esteem and well-being - introductory research by Alina KałużnaWielobób is an article verifying theoretical assumptions of Adler. Using her own tool author checked whether the hypothesis derived from Adler's theory may indeed be confirmed in empirical research.

In the next part of this issue there are several articles in the field of work and organizational psychology. Two of them concern the problem of work engagement. The team: Anita Pollak, Małgorzata Chrupała-Pniak, Patrycja Rudnicka and Mateusz Paliga in article titled Work Engagement - A Systematic Review of Polish Research presents the gathered data of the current state of research on that variable in Poland.

Both work engagement and commitment to the organization, on the other hand, was taken into account by Anna Borkowska and Agnieszka Czerw. Their article Organizational roles and the work and organizational engagement presents analysis of qualitative research, individual and group interviews, conducted in a luxury hotel. The authors have considered the impact of the organizational role on the work engagement and commitment to the organization.

Another text refers to job crafting, a topic still little explored in Poland. Marta Roczniewska and Malwina Puchalska-Kamińska in their article Are managers also 'crafting leaders'? The link between organizational rank, autonomy, and job crafting have focused on particular problem: comparison of job crafting frequency made by managers and subordinates. They have also checked what role a sense of autonomy among workers of different management levels can play in the process of job crafting.

An article Positivity and job burnout in emergency personnel: examining linear and curvilinear relationship by Beata Basinska and Ewa Gruszczyńska concerns the specifics of the relationship between two contrasting variables: positivity ratio (in the work context) and job burnout. The authors reach to an interesting conclusion about curvelinearity of this relationship, at least in the case of two dimensions of job burnout.

The special issue ends with two articles presenting the tools diagnosing important variables, from the positive psychology point of view.

A new method to measure flow in professional tasks - A FLOW-W questionnaire (FLOW at Work) by Beata Wolfigiel and Agnieszka Czerw presents the new Polish tool inspired by Csikszentmihalyi's theory of flow and Bakker's theory of flow at work. The authors emphasize that Bakker's theoretical assumption of two dimensions of flow experienced in the context of work was not confirmed in their research.

In the last article, Psychometric Properties of the Polish Version of the Short Grit Scale Patrycja Wyszyńska, Klaudia Ponikiewska, Dominika Karaś, Małgorzata Najderska and Radosław Rogoza present Polish version of the questionnaire, functioning already in the world literature. Grit is understood here as the perseverance and passion for long-term goals. The authors in their study confirmed the two-dimensions structure of this questionnaire.

\section{References}

Gable, S.L., \& Haidt, J. (2005). What (and why) is positive psychology? Review of general psychology, 9(2), 103.

Gulla, B., \& Tucholska, K. (2007). Psychologia pozytywna: cele naukowobadawcze i aplikacyjne oraz sposób ich realizacji [Positive psychology: the goals of scientific research and application and the manner of their implementation]. Studia z psychologii w KUL, 14, 133-152.

Held, B.S. (2004). The negative side of positive psychology. Journal of Humanistic Psychology, 44(1), 9-46. doi: 10.1177/0022167803259645

Kwiatek, P., \& Wilczewska, K. (2015). Czym jest a czym nie jest psychologia pozytywna? Poszukiwanie paradygmatu [What it is and what is not positive psychology? Searching for paradigm]. Seminare. Poszukiwania naukowe, 4(36), 135-145.

Sundararajan, L. (2005). Happiness Donut: A Confucian Critique of Positive Psychology. Journal of Theoretical and Philosophical Psychology, 25(1), 35 .

Tucholska, K., \& Gulla, B. (2007). Psychologia pozytywna - krytyczna analiza koncepcji [Positive psychology - Critical analysis of the concept]. Studia z psychologii w KUL, 14, 107-131. 